\title{
Multiliteracies and Multimodality in Teaching a Spanish Literature Classic: Don Quixote
}

\author{
Loretta Fernández \\ Visiting Assistant Professor, University of Pittsburgh \\ Contingencies: A Journal of Global Pedagogy, volume 1, number 1, Spring 2021; \\ https://doi.org/10.33682/ghpg-jfun
}

\begin{abstract}
This article analyzes how a multimodal classroom intervention mediated the literacy-learning of Spanish as a foreign language (SPFL). Applying an autoethnographic reconstruction (Ellis et al. 278), this study analyzes how a class redesigned the Spanish literature classic Don Quixote, transforming it into a play and then into an object of reflective practice. Concepts from Multiliteracies pedagogy (New London Group 35), sociocultural theory (Vygotsky 24), and the multimodal social semiotic perspective on literacy (Jewitt 241; Chisholm 257) are employed to analyze the effectiveness of the intervention. The article also proposes an analysis of various classroom activities and how these mediated and fostered communication and interactions in Spanish. The discussion focuses on the utility of complex literacy experience to improve foreign language (FL) teaching and learning. The article concludes by framing FL teaching and learning as a situated practice in which students are engaged in the analysis and the redesign of a literary text in a critical framework (Kern 2000).
\end{abstract}

Keywords: Foreign language teaching and learning, literacy, literature, multiliteracies, multimodality, classroom practices, Don Quixote.

\section{Introduction}

This article analyzes how a multimodal classroom intervention mediated the literacy-learning of Spanish as a foreign language (SPFL). A complex learning experience was presented to an Italian high school SPFL class, an intervention in which students could be engaged in reflecting on and redesigning a cultural artifact. In this case, the artifact was $E l$ ingenioso hidalgo don Quixote de la Mancha ${ }^{1}$ (hereafter referred to as Don Quixote), written by Miguel de Cervantes Saavedra and redesigned as Don Quixote of the Class $4^{\text {th }} \mathrm{M}$.

\footnotetext{
${ }^{1}$ In the classroom, we read a text modified to the expected language level B1 of the Common European Framework of Reference for Foreign Languages (Cervantes 2007).
} 
I was teaching a SPFL class in a fourth-year high school classroom in Palermo, Italy (equivalent to $11^{\text {th }}$ grade in the United States). In the traditional way of presenting Don Quixote, the teacher introduces the text as historical literature, providing background on the author and a summary of the story and its meaning. I decided to structure the Don Quixote curriculum in a different way for my students, however: as an interactive SPFL experience that promoted language- and literacy-learning. Over a period of four months during single hourly lessons, we read, re-wrote, discussed, played with, represented, and criticized the text through our own approaches. Don Quixote became our text. This study examines the experience of a high school classroom in Italy, but it can be adapted to different contexts, including the university foreign language (FL) classroom. The reflection and analysis this investigation yielded could also benefit teacher education programs, as they illustrate the deconstruction of a complex FL multiliteracies practice.

I've used a micro-autoethnographic methodology to reconstruct the data for this paper. To aid my retrospective reflection, I utilized my final report of the intervention, and a draft of the text the students wrote and used for our theatrical representation. Autoethnography refers to the practice of writing about a personal experience in relation to the culture in which the writer is embedded. It is an autobiographical genre of writing and research that shows multiple layers of consciousness. Autoethnography has been used in higher education as a methodology that unites personal experience with theoretical reflection and offers access to an insider's perspective (Ellis et al. 277). In the case of this study, the methodology captures the moment-by-moment progression of a teaching experience that lasted four months, which is why I call it micro-autoethnography, recalling the concept of micro-genesis (Vygotsky 97). This study does not include the voices of the students; rather, it explores a teacher's insights into a specific 
intervention, analyzing it through a specific theoretical framework. Moreover, I argue that this reflective practice could enhance the training of future FL teachers.

This article is divided into four parts: literature review, methodology, analysis and implications, and conclusions. The theoretical framework used to explain this multimodal intervention will consider concepts from Vygotsky's sociocultural theory and concepts from two pedagogical frameworks: multiliteracies pedagogy (New London Group 1997) and the multimodal social semiotic perspective on literacy (Chisholm 87; Jewitt 243; Kress 87; van Leeuwen 584). After my analytical discussion of the teaching model, I discuss the feasibility of similar interventions in the FL classroom in order to provide suggestions for future research and applications of the model.

\section{Literature Review}

\section{Co-construction of learning in the FL field}

A foreign language classroom is often full of expectations, those of the students and those of the teachers. Teachers and students dream, hope, and expect that, at a certain point, students will be able to communicate and interact, and that this interaction will be rich, intense, and exclusively in the target language. This rarely happens, however (Jamshidnejad 3758). Despite years of studying an FL, learners often find themselves unable to communicate their intended meanings or to interact in the FL. Interaction is one of the main goals of FL standards (National Standards Collaborative Board 120). Interaction generates social practices that mediate the learning of language (Lantolf 79). Interaction is also fundamental to the development of language competence (Young 94). Whereas, when learning a second language, students are exposed to the language during their everyday life, in an FL learning context, interactive 
activities are often the only occasion when students get exposure to the cultural and communicative patterns in the FL (Fernández 218). What communication in an FL classroom entails, however, is often not clear.

In the FL field, communication has been defined as "the personal expression, interpretation, and negotiation of meaning where information, feelings, and ideas are exchanged in talk, gestures, and writing" (Adair-Hauck and Donato 265). This definition foregrounds two important aspects of FL learning. First, it emphasizes meaning-formation as a process of personal expression and interpretation in which the individual is actively engaged in the negotiation of meaning. Second, it presents communication as an exchange not only of information but also of feelings and ideas, implying that the communicative exchange can have many forms of expression: talk, gestures, writing, multimedia. Adair-Hauck and Donato's (265) definition of communication provides the conceptualization of literacy applied in this article. In the FL field, literacy is often seen as a subset of language use, mainly the ability to read and write (Warner and Dupuy 118). Here, literacy is instead defined as sociocultural, historical, and critical meaning-making competencies that utilize multimodal tools to convey meaning.

The use of systems of meaning-making, or semiotic systems, leads humans to specific structures of behavior that break away from pure biological development and create new forms of culturally-based psychological processes (Lantolf and Thorne 13). Semiotic acts are meaningful, and meaning can be construed by various semiotic modalities, of which language, spoken or written, is only one instance. Semiotic systems (i.e., words, music, images, multimedia) mediate the process of learning (Halliday 94). In this article, the concept of mediation (Vygotsky 54-55) offers a theoretical explanation of how interactive collaborative 
activities can support the acquisition of FL language, literacy, and culture, and how learning is co-constructed through collective work.

Mediation is a key concept for sociocultural theory; in the educational field, it refers to those means - activities and tools - externally presented to learners in order to assist and support their mental development (Vygotsky 54). The use of literacy activities in an FL classroom can have a twofold mediational purpose. On the one hand, it can mediate authentic language; on the other, it can mediate the history, culture, and society of the studied text (Glisan and Donato 115). In this case, I used Don Quixote, which is not only a work of literature, but a world-renowned icon of Spanish literature. Even a masterpiece like Don Quixote, however, is not mediational as a tool per se; it must be used and presented by the teacher in the classroom in a way that is significant to the students in order to promote learning.

\section{Connection in interaction}

The Connections Standard, in the National Standards Collaborative Board (2015), highlights the necessity to favor connections between FL study and other disciplines, such as art, music, history, and film studies, among others. Most of the time, the implementation of this standard in the FL classroom is very difficult. Students often have contact with the FL only in a classroom context and this limits their exposure to the cultural texts presented in the classroom. To enact this standard, Kern (2008) suggests a textual interpretation that connects texts with other disciplines and perspectives; since texts are vehicles of culture, it is important for teachers to provide multiple perspectives on the texts they use, rather than privileging the perspectives of hegemonic cultures. 
Given that the use of texts in an FL classroom is an act of cultural propagation, they should not only be used to practice vocabulary or grammatical structures, but also to engage students in the discovery of new cultural perspectives. Culture, as Kramsch (79) explains, is present in both native- and non-native-speaker communicative practices. Thus, the link between language and culture needs to be highlighted within the context of FL teaching. Kern (368) calls connections-enhanced teaching a way of teaching that promotes cultural and disciplinary value by engaging students in interactive activities.

Interactive activities are the best way to promote connections between new cultural perspectives and the ones that students already possess. Interaction, in a connection-enhanced context, promotes critical thinking; students are engaged in communicative dialogues in which they compare their culture with the target-language culture. Kern (370) bases his teaching theory on Halliday's concept of language as a social semiotic (Halliday 11), in which culture itself is conceived as encoding multiple layers of meaning. In this layered system, there is no longer a linear reading, but many ways of reading that allow alternative ways to make sense of a text.

\section{Pedagogy of multiliteracies}

Now more than ever, our hyper-specialized and highly-competitive world requires students to communicate and interact in an FL in a meaningful and effective way (Jewitt 243; Kramsch 32). Consequently, at the end of the last century The New London Group (1996) emphasized how the negotiation of meaning-making processes enacted in dialogic activities helps individuals feel valued in global contexts. FL education becomes a key instrument for improving global exchange, but to be effective, this education should connect the learner to the cultural context in which the language is spoken. 
The New London Group proposed the pedagogy of multiliteracies (61), in which the world changes around the individual to design new learning processes. Designing is the act of shaping, re-presenting, and re-contextualizing meaning. When students design a new meaning there is a base, or available design, that is re-shaped in order to make new meaning. The output of this activity is the redesign. The redesign is not a copy of the available design; it is a completely new product that comprises not only the available design but also the agency, the self of the meaning maker, in transforming the meaning (New London Group 76).

A direct application of multiliteracies pedagogy is Learning by Design pedagogy (Cope and Kalantzis 4; Kalantzis et al. 203), which emphasizes redesign in terms of diversity, multimodality, overt instruction, and critical framing. There are several studies reporting positive results from the application of multiliteracies pedagogy and Learning by Design (see Zapata and Lacorte 1-235 for a review of studies). Most of these studies have reported results concerning the analysis of classroom talk (teacher-student talk or student-student talk) (Anstey and Bull 160), but to my knowledge there are no studies that report the use of autoethnography by teachers to examine the application of multiliteracies pedagogy in their teaching.

\section{Methodology}

\section{Context}

The intervention I am presenting took place in Palermo, Italy. In Italy, high school students must choose a field of concentration for their high school degree. The FL-oriented high school where this study took place is Liceo Regina Margherita. This school not only offers a high school diploma in Liceo Linguistico (FL-oriented diploma), but also a Socio-Psycho-Pedagogic high school diploma, and a Social Sciences high school diploma. One of only four linguistic high 
schools in Palermo, and located downtown, Liceo Regina Margherita draws students from diverse backgrounds across the city.

In the Liceo Linguistico, language and literature are conceived as two separate subjects. The study of language follows the communicative approach. Teachers use functional language aimed at real-life situations and use integrated communicative skills (speaking, writing, reading, and listening). Nevertheless, a significant amount of time is also dedicated to grammar instruction. The study of literature is mainly the chronological study of the history of literature taught in the target language. Each class also includes one hour per week during which a native-speaker teacher provides instruction in conversation and culture in order to give students an opportunity for real-life interaction. The conversation classes are usually organized as a discussion around a specific topic (e.g., food, festivities, school systems in Spain and South America) proposed by the teacher.

\section{Participants}

In this study, I was the native-speaker teacher, and I proposed a four-month intervention focusing on Don Quixote. Class 4th M was comprised of 24 students: 18 identifying as female and six identifying as male, ranging in age from 17 to 19 years old, and coming from different socioeconomic backgrounds. The idea of a collaborative, interactive intervention involving Don Quixote elicited excitement from the students.

\section{Data sources and analysis}

I reconstructed the data for this paper using my experience as a teacher (Ellis et al. 278). In order to triangulate the data, I also used a final report of the intervention that I presented to the school, and a copy of the script of the play created by Class $4^{\text {th }} \mathrm{M}$ (Patton 431$)$. To access 
multiple layers of consciousness, I first jotted notes regarding my memories of the intervention. Next, I triangulated my notes with the other data sources. Then, I reflected on the moment-by-moment activities in light of the theoretical frameworks I'd applied. Finally, I reflected on the ways this micro-autoethnography could contribute to higher education.

\section{Realization of the classroom intervention}

The intervention of the theatrical transposition of Don Quixote made use of a simplified version of Don Quixote de la Mancha with an audio CD. The audio book, Available Design, (New London Group 28; Allen 89) was the basis for the Class $4^{\text {th }} \mathrm{M}$ design (New London Group 29) of Don Quixote. I helped the students to redesign the text into a theatrical play using different modes of communication and activities, and explained to them that each mode of communication contributed to the meaning of the redesign (Jewitt 253; Kern 375).

Students volunteered during class activities for the different roles in the intervention. Small groups worked on different modes of communication, i.e., scriptwriters, stage directors, actors, lighting designers, sound designers, and scenic designers. Their objective was to achieve the success of the whole production. Each of the students, independently of their role, was assessed using the same grading criteria. Having different roles helped students ensure the quality of the production as a complex multiliteracies experience. The intervention was organized in different phases, which are explained below.

\section{Structure of the intervention}

Phase 1: The students read the text, listened to the audio CD in class and in their homes, and analyzed the scenes, characters, and language of Don Quixote in a whole-class discussion in 
Spanish. I designed a game to help students better understand each character of the play. For the game, the class was divided into groups; the students were encouraged to use Spanish but they could use Italian when necessary. Then, the students in each group chose a character and became that character's lawyer. The students had to defend the choices that each character makes during the course of Don Quixote. For example, one student would defend Don Quixote's choices, while another would defend Sancho's, or Dulcinea's, according to the character's social status, psychology, and relationship to their culture. Then, the students compared the character's choices in the book to what the students would do if the plot happened in the $21^{\text {st }}$ century.

This activity generated interactive conditions in class and mediated the students' approach to the text. For example, a student acting as Dulcinea's lawyer explained that during the story the character is never aware of Don Quixote's veneration of her; instead, she responds to Don Quixote's advances because she is sympathetic to his unorthodox actions. Don Quixote's lawyer said that Dulcinea knows of Don Quixote's love and enjoys being someone's object of affection, and this is the reason for her kindness towards him. Through the game, students established how they wanted to represent each character on stage. Exploring different perspectives on iconic literary characters introduced the idea that there was more than one way of interpreting the text. Vygotsky (1978) emphasizes the immense importance of social interaction in the process of creating meaning through mediation. This game was a tool to mediate students' meaning-making process while they examined Don Quixote in depth.

Delving deeper into the content of Don Quixote, students engaged in situated practice through the creation of a stage play (New London Group 33). They worked in groups to transform the text first into a script, and then into a production. This activity immersed students in practical language use through collaborative interaction (Allen 95; Paesani 162). 
Phase 2: The student's redesign of the work of literature reimagined the text in a new form. While reading Don Quixote, the students decided which scenes they wanted to include in the play and why. They decided on costumes, lighting, sound, and all other aspects of the production. The decision-making process required the students to interact in Spanish, establishing a purposeful collaboration geared toward the completion of the play. Thus, the redesign gave the students the opportunity to collaborate in the target language for a real-life purpose.

As an example of the redesign of Don Quixote, I compare below the beginning of Cervantes' text with the beginning of our play. The translation is by Ormsby.

From the original text of Don Quixote (Spanish edition cited in the Works Cited section):

\section{Capítulo primero}

1 En un lugar de la Mancha, de cuyo nombre no quiero acordarme no ha mucho tiempo que vivía un hidalgo de los de lanza en astillero, adarga antigua, rocín flaco y galgo corredor. Una olla de algo más vaca que carnero, salpicón las más noches, duelos y quebrantos los sábados, lentejas los viernes, algún palomino de añadidura los domingos, 5 consumían las tres partes de su hacienda. El respeto de ella concluía sayo de velarte, calzas de velludo para las fiestas, con sus pantuflos de lo mismo... tenía en su casa una ama que pasaba de los cuarenta, y una sobrina que no llegaba a los veinte...En resolución, él se enfrasco tanto en su lectura, que se le pasaban las noches leyendo de claro en claro, y los días de turbio en turbio; y así del poco dormir y de mucho leer se le 10 seco el cerebro, de manera que vino a perder el juicio. ${ }^{2}$

(Cervantes 23-26)

\footnotetext{
${ }^{2}$ In a village of La Mancha, the name of which I have no desire to recall, there lived not long ago one of those gentlemen who keep a lance in the lance-rack, an old buckler, a lean hack, and a greyhound for coursing. An olla of rather more beef than mutton, a salad on most nights, scraps on Saturdays, lentils on Fridays, and some extra pigeon on Sundays made away with three-quarters of his income. The rest of it went in a doublet of fine cloth and velvet breeches and shoes to match for holidays, while on weekdays he made a brave figure in his best homespun. He had in his house a housekeeper past forty, a niece under twenty, and a lad for the field and marketplace, who used to saddle the hack as well as handle the bill-hook...In short, his wits being quite gone from reading night and day and not sleeping, he hit upon the strangest notion that ever madman in this world hit upon... (Cervantes 2004)
} 
From the draft of Don Quixote by Class 4th M. The translation is mine.

\section{ACTO I, Escena I}

1 Narrador: en un lugar de la mancha, de cuyo nombre no quiero acordarme, no hace mucho tiempo vivía un hidalgo, que tenía en su casa un ama que pasaba de los cuarenta, y una sobrina que no llegaba a los veinte. Alcanzaba la edad de cincuenta años; era madrugador y amigo de la caza. Tenía el sobrenombre de Quijada o Quesada.

5 Este hidalgo, los ratos que estaba inactivo, que eran los más del año, leía los libros de caballerías con tanta propensión y gusto que olvidaba la caza e incluso la administración de su hacienda. Con estas lecturas perdía el caballero la razón. Leía tanto que le pasaban las noches leyendo de claro en claro, y los días estaban somnolientos. Un día de estos, Don Quijote estaba asentado en su casa mientras leía un 10 libro de caballería. Alrededor de él estaban la ama y la sobrina que limpiaban la habitación y le hablaban constantemente. Pero él no les daba cuerda.

Ama: ¿Qué lee señor? (dos, tres veces)

Sobrina: ¿Qué haces tío?

Don Quijote: (distraido, sigue leyendo) ${ }^{3}$

The script created by Class $4^{\text {th }} \mathrm{M}$ repeated the first and most famous sentence of $D o n$ Quixote "En un lugar de la Mancha..." (line 1). Immediately after, the Class $4^{\text {th }} \mathrm{M}$ script used vocabulary studied in the Spanish class in its description of the household. One example is when the students wrote "la administración de su hacienda" (line 7) instead of "consumían las tres partes de su hacienda" (Cervantes, line 5). In their redesign, the students decided to use a simpler

\footnotetext{
${ }^{3}$ ACT I, Scene i. Narrator: In a place of La Mancha, whose name I do not want to remember, not long ago lived a noble hidalgo, who lived with a housekeeper in her mid-forties, and a niece that was not yet twenty years old. He was about fifty years old. He was an early riser and a friend of hunting. He was called Quijada or Quesada. This noble hidalgo, when he was inactive, which was most of the year, would read books of chivalry with such pleasure and propensity that he was able to forget the hunt, and even the administration of his state. With these readings the nobleman lost his reason. He spent nights reading from dusk to dawn, and thus his days were sleepy. On one of those days, Don Quixote sat at home while reading a book of chivalry. With him were his housekeeper and his niece, cleaning the room and talking to him constantly. But he paid them no attention.

AMA: What are you reading sir? (two, three times)

NIECE: What are you doing, uncle?

DON QUIJOTE: (distracted, continues reading)
} 
language, modernizing the text and making the story more accessible to language learners such as themselves, or to their peers who served as the audience.

Many of the details regarding Don Quixote's domestic setting that are present in Cervantes' text were omitted in the Class $4^{\text {th }} \mathrm{M}$ text. One example can be found in Cervantes line 2: "hace mucho tiempo que vivía un hidalgo de los de lanza en astillero, adarga antigua, rocín flaco y galgo corridor." Compared to the novel, written for literate seventeenth-century readers, the Class $4^{\text {th }} \mathrm{M}$ redesign involved a new genre and a new audience. The redesign was created for a stage production presented to an audience comprised mainly of students and teachers. The script was written in a more concise language than the one used in Cervantes' novel. Additionally, the Class $4^{\text {th }} \mathrm{M}$ text focused more on the characters' actions than on the words. Nevertheless, the Class $4^{\text {th }} \mathrm{M}$ script preserved the old-fashioned ambiance and other iconic aspects of Cervantes' novel by retaining the introduction "En un lugar de la Mancha...."

When applying the pedagogy of multiliteracies as a framework for analysis (New London Group 34), each element of the modes of meaning was important in order to interpret and design the context. I suggested a division of labor using different groups of students to represent each mode of meaning. I participated actively in guiding the different groups and their use of the Spanish language for real communication purposes. Each of the groups was working with a different mode of meaning, and each of these modes had equal value in working toward the completion of the intervention.

- Group of four writers: These students wrote the script for the play based on scenes from the book. This is called linguistic design in multiliteracies pedagogy (New London Group 1997). For example, this group created the text with an audience of Spanish students, rather than L1 speakers, in mind. On multiple occasions, the students avoided complex 
words, instead choosing words that were easy to recognize. For example, in the Class $4^{\text {th }}$ M excerpt quoted above, line 8 (“Con estas lecturas perdía el caballero la razón’ [with these readings the gentleman lost his mind]) is used instead of Cervantes, lines 9-10 ("y así del poco dormir y de mucho leer se le seco el cerebro, de manera que vino a perder el juicio" [In short, his wits being quite gone from reading night and day and not sleeping]). The Class $4^{\text {th }} \mathrm{M}$ text enabled the audience to understand what was happening. Cervantes' text uses more elaborate descriptions to illustrate Don Quixote's madness.

- Group of nine actors: These students interpreted the written scenes and staged the speech, movement, and gesture of each action, adding further meaning to the text written by the group of writers. Two of the students in this group who had minor roles, El Ama (the housekeeper) and La Sobrina (the niece), were involved in the blocking and direction of the scenes, which is part of the visual design. For example, in a scene where there are secondary actors socializing in a casual interaction, the visual designer directed the actors to act naturally as if they were talking to their peers. In contrast, the actor playing Don Quixote, who, according to the students, was interpreting a character living in his own reality, was directed to gesticulate in an exaggerated manner in order to depict the character's extroverted nature.

- Group of four scenic and costume designers: These students interpreted the scenes written by the group of writers and designed the set and costumes for the play. According to the modes of meaning presented by the New London Group (27), the students of this group conducted a visual designing and a spatial designing of the text, which added further meaning to the written text of the writers' group. For example, these students decided that the characters would wear everyday clothes, but they also decided that the 
actors should wear something that reminded the audience that the play was in another era. Thus, Don Quixote wore a ruffled shirt with shorts and sneakers.

- Group of three lighting and sound designers: These students recognized that while lighting and music were background elements of the play, they were important on the set, necessary to give dramatic meaning to the story. Lighting and sound design were as important for the realization of the play as linguistic design. For example, while Don Quixote was on stage, the lights started to flash violently and in different colors, signifying the mental processes of the character.

During the production process of Don Quixote, students made different modes of meaning. A multimodality approach (Jewitt 246; Chilsholm 73) can explain how meaning constructed through language, gesture, gaze, speech, movement, sound, color, and lighting had relevance for the play, but also for the FL learning process. Through the mediation of the FL, the students explored not only the text and its culture but also other modes of meaning-making.

Phase 3: The script was read aloud in class by the group of writers and critiqued by the whole class. Many changes to the script were made during this activity. Each student had the opportunity to apply critical thinking skills comparing the historical characteristics of the period in which Don Quixote was written with the characteristics of the one in which they were living. They reflected on the aspects of the story that were relevant to them and worth representing in the play. This constant discussion mediated the students' designing and redesigning of the text. The process of redesigning continued throughout the whole production period. Each group contributed not only to their assigned area but also to other groups' work. The writers helped the actors in their interpretation of the text; the sound and lighting group and the set and costume group were constantly communicating. In this sense, the text was not the Don Quixote of Miguel 
de Cervantes Saavedra; it was the students' own creation. They were taking possession of their own text, and it was Don Quixote of the Class $4^{\text {th }} M$. The production was presented twice in the school's theater. The audience was comprised of all the Spanish classes in the school and many of the teachers.

Phase 4: The assessment aimed to give a critical frame to the intervention and, at the same time, to assess the students' critical literacy. Critical Framing, according to the New London Group (34), considers students' questions and critical reflections within specific content. In this phase of the intervention, students used critical thinking to question what was taught and how it was taught. Developing questions during Critical Framing enabled the students to understand and process new information more effectively, and their questions helped me to understand how the students lived the experience and how it could be improved.

\section{Assessment}

The assessment was divided in two activities: a critical framing-based, interactive, whole-class discussion and a written task that students had to produce documenting their critical analysis of the play. The written task was part of the summative assessment. Students had to write about one of these two prompts:

1. Write a journal reflection about your experience working on the play. What was your individual role and contribution to the play? What did you want to communicate through your work on the play? Do you think the play was similar to or different from the book Don Quixote? Why? Are you happy with your work? Why? What would you change about the work you and your group did? Did you enjoy learning in this way? Why? What would you change? 
2. Write a newspaper article about the new version of Don Quixote produced by your class. Explain how it is similar to or different from the novel by Cervantes. How important was it for you (a young Sicilian) that this play was produced in this way? Which elements of the play demonstrate its originality, and why are they original? What would you change about the play and why? Would you recommend this educational experience to others? Why?

Eager to express their opinion about their work, the students found the writing tasks meaningful. The critical review of their work, apart from its value as formal assessment, mediated their process of self-reflection and was an occasion of reflective practice. Students wrote about their contributions to the production, and why the experience was meaningful for them and for the Liceo Regina Margherita Spanish students as a community. This part of the process afforded me the opportunity to consider the tasks included in the intervention and their pedagogical effectiveness.

\section{Analysis and Implications}

The research methodology of micro-autoethnography (Ellis et al. 282) that I used as a lens to analyze this significant experience of teaching and learning gave me the opportunity to reflect on my own practice. In this self-inquiry, understanding the relationship among my classroom practices and language and literacy theories was essential to understanding the educational issues underpinning my pedagogy. Microgenetic refers to the possibility I had to follow the evolution of the whole intervention moment-by-moment as a participant. Observing the intervention through the lens of a researcher, and through the distance of time, gave me the opportunity to re-conceptualize it in a coherent and explanatory framework. 
Throughout the exposition of the preceding sections, I offered different interpretations of the various activities conducted in my classroom intervention. I used some important pedagogical concepts and literacy theories to provide a conceptual framework for my analysis. Taking Vygotsky's sociocultural theory as a key framework, I showed how mediation through cultural artifacts can help the development of higher-order thinking, such as reflection and analysis.

My own analysis entailed understanding how an historic Spanish work of art could be meaningful to students in the twenty-first century, and how Don Quixote could provide the occasion to interact in an FL. My objective was not only to present an important literary text, but also to guide the students through different activities that would help them to understand a text as a vehicle of language, literacy, and culture. The students recreated Don Quixote in play form using their own knowledge of the FL mixed with the language utilized by Cervantes in his original text. They used sound and scenic design to recreate the premise of the lunatic landlord who was convinced he was a knight, and to depict how re-entering the conventional world led to Quixote's death.

Redesigning an available design (New London Group 1996) such as Don Quixote de la Mancha could be considered a successful pedagogical practice situated in the school context. Don Quixote was not only a novel of the Siglo de Oro (Golden Age) of Spanish literature, but also a window into Spanish tradition and culture (Cervantes talks about food, religion, politics, love, and social interactions) and an opportunity for students to connect to the world of the text and reflect on their own culture. Students critically thought about Spain and Sicily, Spanish literature and Italian literature, and Don Quixote, Sancho Panza, and many other characters in relation to themselves. 
One of the main objectives of the pedagogy of multiliteracies is to transform school and school literacy (New London Group 1996). A point of weakness in my analysis could be traced to the initial objectives of the Don Quixote intervention. I proposed this intervention to help students learn language, literacy, and culture through collaborative interaction. The aim was not directly to transform school practice, although that was a consequence of this initiative. It is now my belief that the production of Don Quixote mediated students' critical understanding of the complexity and connectedness of multimodal literacy practices while favoring occasions for real classroom interaction.

Critically framing a pedagogical experience helped me as a teacher to develop an understanding of my students and my subject area. Moreover, critical framing allowed me to generate affective boundaries between the students' culture and society and other cultural and social worlds such as Spain in the Siglo de Oro. The Don Quixote intervention changed the way I teach Spanish conversation. During the intervention, I was no longer merely the person proposing a topic for discussion. Students came to class and started to converse on their own initiative in the target FL. I was not just the teacher; I was one of the crew members of the show. We each had our own role, and we were working towards the completion of our collective goal in Spanish.

This study comes with some limitations. It is a reconstruction, and it has limited data sources. Moreover, it presents the sole perspective of the teacher-researcher. The implications of the ex-post analysis I've offered here and the theoretical framework I used could, however, provide a blueprint for the implementation of similar interventions in FL classrooms. The self-reflection and analysis of pedagogical practice through the lenses of theories such as the 
ones presented here can be a tool for reflection in teacher education programs. Future research in this area could provide more data to support these claims.

The intervention took place in a high school setting, but the concepts and strategies I used could be implemented in a higher education foreign language classroom given that this intervention offered a collaborative, purposeful transformation of a literature classic that

promoted real FL interaction. In most U.S. university FL programs, courses are articulated in two blocks: 1) lower-level language courses, and 2) upper-level literature courses where there is little to no intersection between language and literature teaching and learning. Authors (Allen 88;

Kern 371; Paesani 162) have advocated for an integration of literature and language instruction in higher education, where literature becomes a means to connect language and culture, generating literacy-learning and promoting translingual and transcultural competencies (Paesani 174). This article explores an intervention that indicated how language, literacy, and culture could be integrated in a multiliteracy and multimodal curriculum in a way that promoted real occasions for FL interaction.

\section{Conclusions}

The field of FL education has a stake in defining and understanding how rapid changes in the contemporary world can provide new opportunities for the study of other languages and cultures (Jewitt 241; Kramsch 306). The FL field needs to open itself to new literacy scenarios in which different modalities of semiotic meaning-making shape and influence pedagogy (Paesani 168). Teachers can offer students the possibility of meaningful interactions that mediate their literacy-learning through complex activities that reshape classroom practice. The collaborative co-construction of meaning can help students to acquire language proficiency and connect with 
the literacy and culture of the speakers of the FL (Glisan and Donato 20). Teacher education programs should offer candidates the possibility to deconstruct teaching practices, such as the one offered in this article, in order to reflect on ways of teaching the differences in attitudes, behaviors, and worldviews of an FL culture. Moreover, higher education institutions can offer courses that explore the complex intersections among language, literacy, and culture.

To conclude, I present one more point of reflection: can this production of Don Quixote be analyzed as transformed practice? The New London Group (35-36) defines transformed practice as theory that becomes reflective practice:

"With their students, teachers need to develop ways in which the students can demonstrate how they can design and carry out, in a reflective manner, new practices embedded in their goals and values. They should be able to show that they can implement understanding acquired through Overt Instruction and Critical Framing in practices that help them simultaneously to apply and revise what they have learned. In Transformed Practice we are offered a place for situated, contextualized assessment of learners and the learning processes devised for them. Such learning processes, such pedagogy, need to be continually reformulated on the basis of these assessments" (New London Group 35).

I would argue that it is possible to view this intervention as transformed practice. Cervantes powerfully advanced a critique of the social constraints placed on those who envision the world from a highly personal perspective (Don Quixote's madness). He presented a profound reflection about the changing world and the capacity of humans to adapt to those changes, which after more than four hundred years remains a contemporary topic. The intervention presented 
here qualifies as transformed practice because it allowed a reconceptualization of the

pedagogical approach to a literary classic, informed by new meanings and cultural dynamism.

\section{Works Cited}

Adair-Hauck, Bonnie, and Richard Donato. "The PACE Model: A Story-Based Approach to Meaning and Form for Standards-Based Language Learning." French Review, vol. 76, no. 2, 2002, pp. 265-76.

Allen, Heather Willis. "Beyond the language-literature divide: Advanced pedagogy for training graduate students." ADFL Bulletin, vol. 41, no. 2, 2009, pp. 88-99. http://works.bepress.com/heatherwillisallen/22/. Accessed 01 April 2021.

Anstey, Michèle, and Geoff Bull. Foundations of Multiliteracies: Reading, Writing and Talking in the 21st Century. Routledge, 2018.

Cervantes, Miguel. El Ingenioso Hidalgo Don Quijote de la Mancha. Visión Libros, 1984.

Cervantes, Miguel. Don Quixote. Translated by John Ormsby. Gutenberg e-book ed., 2004. Don Quixote, by Miguel de Cervantes (gutenberg.org). Accessed 01 April 2021.

Cervantes, Miguel. Don Quijote de la Mancha. Adapted by Flavia Bocchino Ramazio, CIDEB, 2007.

Chisholm, James S. Leveraging Adolescents' Multimodal Literacies to Promote Dialogic Discussions of Literature in One Secondary English Classroom. 2010. U. of Pittsburgh, PhD dissertation. D-scholarship, http://d-scholarship.pitt.edu/7618/1/JSChisholm2010.pdf.

Cope, Bill, and Mary Kalantzis. A Pedagogy of Multiliteracies: Learning by Design. Palgrave McMillan, 2015.

Ellis, Carol et al. “Autoethnography: An Overview.” Forum Qualitative Sozialforschung / Forum: Qualitative Social Research, vol. 12, no. 1, 2011, art. 1. http://nbn-resolving.de/urn:nbn:de:0114-fqs1101108. Accessed 01 April 2021.

Fernández, Loretta. "Developing Oral Interaction in Italian through the Generic Structure of Typified Situations." Genre in World Language Education: Contextualized Assessment and Learning, edited by Francis Troyan. Routledge, 2021, pp. 217-241. 
Glisan, Eileen W., and Richard Donato. Enacting the Work of Language Instruction: High-Leverage Teaching Practices. The American Council on the Teaching of Foreign Languages, 2017.

Halliday, Michael A. K. Language as Social Semiotic: The Social Interpretation of Language and Meaning. Edward Arnold, 1978.

Jamshidnejad, Alireza. "An Innovative Approach to Understanding Oral Problems in Foreign Language Learning and Communication." Journal of Academic and Applied Studies, vol. 1, no. 1,2011 , pp. 3-31.

Jewitt, Carey. "Multimodality and Literacy in School Classrooms." Review of Research in Education, vol. 32, no. 1, 2008, pp. 241-267.

Kalantzis, Mary, et al. Cultures of Schooling: Pedagogies for Cultural Difference and Social Access. The Falmer Press, 1991.

Kern, Richard. "Making Connections through Texts in Language Teaching." Language Teaching, vol. 41, no. 3, 2008, pp. 367-387.

Kramsch, Claire J. Language and Culture. Series edited by Henry G. Widdowson, Oxford University Press, 1998.

Kramsch, Claire J. "Language and Culture.” AILA Review, vol. 27, 2014, pp. 30-55.

Kress, Gunther R. Multimodality: A Social Semiotic Approach to Contemporary Communication. Routledge, 2010.

Lantolf, James, P., and Steve L. Thorne. Sociocultural Theory and the Genesis of Second Language Development. Oxford University Press, 2011.

Lantolf, James P. "Second Language Learning as a Mediated Process.” Language Teaching, vol. 33, 2000, pp. 79-86.

National Standards Collaborative Board. World-Readiness Standards for Learning Languages. 4th ed. American Council on the Teaching of Foreign Languages (ACTFL), 2015.

New London Group. “A Pedagogy of Multiliteracies: Designing Social Futures.” Harvard Educational Review, vol. 66, 1996, pp. 60-92.

Paesani, Kate. "Research in Language-Literature Instruction: Meeting the Call for Change." Annual Review of Applied Linguistics, vol. 31, 2011, pp. 161-181.

Patton, Michael Q. Qualitative Evaluation and Research Methods. 2nd ed. Sage, 2001. 
van Leeuwen, Theo. "Multimodality in Education: Some Directions and Some Questions." TESOL Quarterly, vol. 49, no. 3, 2015, pp. 582-589.

Vygotsky, Lev S. Mind in Society. Harvard University Press, 1978.

Vygotsky, Lev S. Thought and Language. The MIT Press, 1962.

Warner, Chantelle, and Beatrice Dupuy. "Moving Toward Multiliteracies in Foreign Language Teaching: Past and Present Perspectives...and Beyond." Foreign Language Annals, vol. 51, 2018, pp.116-128.

Young, Richard F. "Interactional Competence and L2 Pragmatics." The Routledge Handbook of Second Language Acquisition and Pragmatics. Edited by Naoko Taguchi, Routledge, 2019, pp. 93-110.

Zapata, Gabriela C., and Manel Lacorte. Multiliteracies Pedagogy and Language Learning: Teaching Spanish to Heritage Speakers. Palgrave Macmillan, 2018. 